\title{
OBSERVATIONS ON BURDOCK- KILLED BIRDS IN KING'S PARK, WINNIPEG, MB
}

TODD J. UNDERWOOD, Department of Zoology, University of Manitoba, Winnipeg MB R3T 2N2 and ROBYN M. UNDERWOOD, Department of Entomology, University of Manitoba, Winnipeg MB R3T 2 N2.

Email: umunderw@cc.umanitoba.ca

Introduced species often have a negative impact on native flora and fauna through competition, predation, ecosystem alteration, hybridization, and introduction of disease..$^{1,6}$ Four species of burdock (Arctium spp.) were introduced into North America from Eurasia. ${ }^{3}$ Common Burdock (A. minus) and giant burdock ( $A$. lappa) are the most common of the four species and are now found throughout southern Canada and the United States. ${ }^{3}$ In order to reproduce, burdock plants produce seed-filled burs that are dispersed by hitching a ride on large animals that come into contact with them. However, for small animals, they can sometimes be deadly.

Recently, the impact of burdock on North American songbirds has received public attention. ${ }^{9}$ Songbirds and other small animals, such as bats and insects, occasionally get entangled in and die on burdock burs., 5, 11 Here, we report details of six new records of burdockkilled birds found in November 2000. We discovered one Least Flycatcher, four Nashville Warblers, and one Tennessee Warbler entangled in the burs of Common Burdock at King's Park in Winnipeg, Manitoba. To our knowledge, these observations are the first records of Least Flycatcher and
Nashville Warbler entanglement in burdock.

\section{Observations}

We found the first bird, a Nashville Warbler, serendipitously while walking through King's Park on 4 November 2000. The warbler was on the edge of a burdock patch approximately $100 \mathrm{~m}$ long by 3-10 $\mathrm{m}$ wide that separated a wooded area from a large area of mowed grass. A more thorough search of this patch left us empty-handed but covered in burs. We then searched other areas of the park on $4,5,11,12$, and 26 November 2000. Our search effort totaled 8 person-hours and yielded five more burdock-killed birds. Two more birds were found on 4 November (another Nashville Warbler and a Least Flycatcher) and single birds were found on 5 (Nashville Warbler), 11 (Nashville Warbler), and 26 November (Tennessee Warbler).

The first Nashville Warbler was hanging upside down $1.1 \mathrm{~m}$ from the ground and $0.2 \mathrm{~m}$ from the top of the plant. It was attached to the burs mostly by feathers of the abdomen and left wing. The legs and tail also were caught (Figure 1). A string of five burs was attached to the breast feathers and left wing, but was not attached to the plant. 


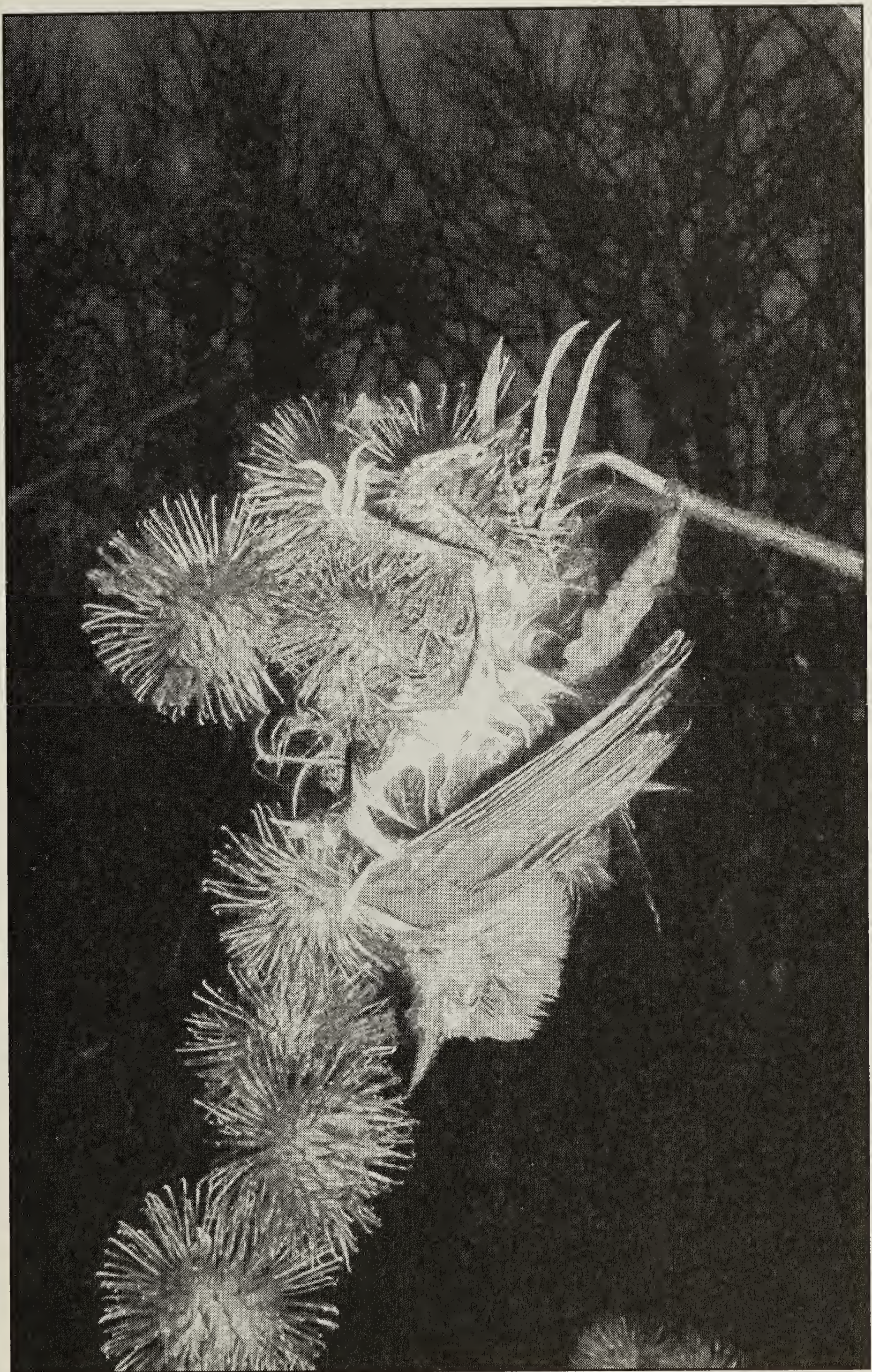

Figure 1. Adult female Nashville Warbler entangled in burdock burs

T. J. Underwood 
The lack of a crown patch, its pale yellow throat and flanks, and rounded primary coverts identified this warbler as an adult (after hatching-year) female. ${ }^{10,7}$

The second Nashville Warbler found on 4 November was located approximately $5 \mathrm{~m}$ from a path in an 8 by $8 \mathrm{~m}$ burdock patch in a sparsely treed area. It was caught between two burdock plants at a height of $1.7 \mathrm{~m}$ at the tip of one plant and $0.2 \mathrm{~m}$ below the top of the other plant. It was attached to the burs of one plant by feathers of the head, legs, right wing, and breast. The back and right wing were attached to the other plant. The feet also were entangled. Because of the poor condition of this specimen, species identification was based on measurements of the bill, wing, and tarsus 10 and comparison of the specimen with study skins in the University of Manitoba Zoology Museum. The exposed skull was completely ossified, indicating that the bird was an adult.

The third bird found on 4 November, a Least Flycatcher, was located in a single $20 \mathrm{~m}$ long row of burdock plants between a row of trees and mowed grass beside a road. It hung upside down $0.9 \mathrm{~m}$ above the ground. The flycatcher was stuck between the tip of one plant and a branch of another plant. The second branch from the top of the second plant was stuck to the right side of the bird. The wings, tail, abdomen and breast were entangled in burs (Figure 2). The buff wing bars, pointed primary coverts, and unworn primaries

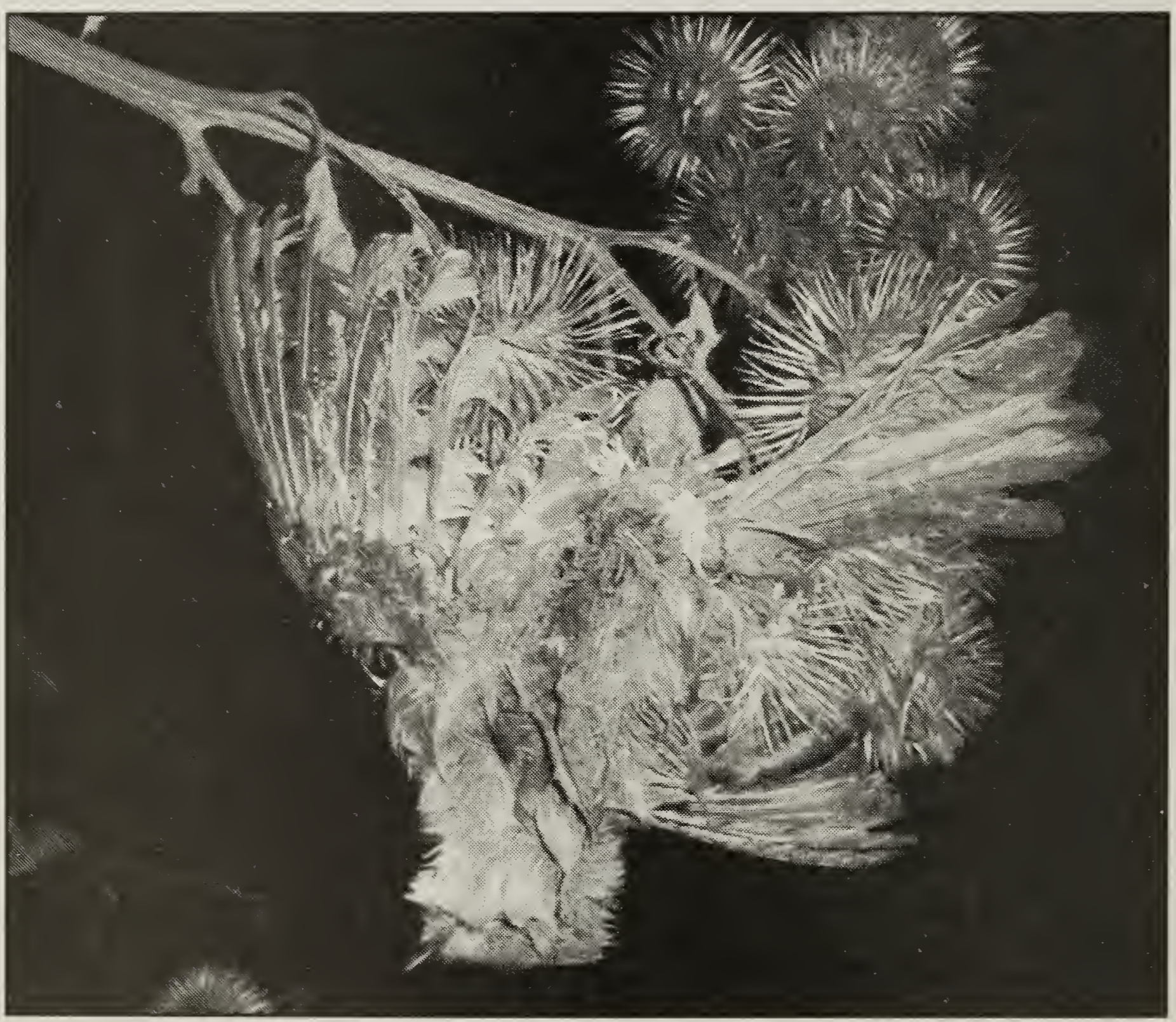

Figure 2. Immature Least Flycatcher entangled in burdock burs

T. J. Underwood 
identified this Least Flycatcher as an immature (hatching-year) bird. ${ }^{7,2}$

The Nashville Warbler discovered on 5 November was in an extensive burdock patch in a forest with a somewhat open canopy. This patch was approximately 75 by $50 \mathrm{~m}$, with a path running through the middle of it. The bird was caught in a plant about 5 $m$ in from the path and hung upside down $1.2 \mathrm{~m}$ above the ground and 0.4 $\mathrm{m}$ from the top of the plant. It was stuck between burs from the first and fourth branches from the top of the plant. The feathers of the breast, right wing, flank, right leg, and right foot were entangled in burs. This Nashville Warbler was identified as an immature (hatchingyear) female because of its buff throat, pale yellow flanks, pointed outer rectrices, and pointed primary coverts. $^{10,7}$

On 11 November, we found the fourth Nashville Warbler in a burdock patch approximately $40 \mathrm{~m}$ long by $1-5 \mathrm{~m}$ wide on the edge of a strip of trees along the Red River. The bird was at the top of a plant, $1.2 \mathrm{~m}$ high, and hung upside down. Burs on the plant were entangled in both wings, legs and feet of the warbler, as well as feathers on the abdomen and left flank. The broad primary coverts and truncate outer rectrices suggest that this bird was an adult (after hatching-year) bird, ${ }^{7}$ but its poor condition makes our age identification somewhat tentative.

The last bird was a Tennessee Warbler discovered on 26 November. The warbler was hanging upside down from the top of a very large burdock plant $2.9 \mathrm{~m}$ high on the edge of a dense 50 by $30 \mathrm{~m}$ patch of burdock located under an opening of the forest canopy. The bird was attached to the burs by the foot and feathers of its left leg. Species identification of this bird was based on its green plumage with white undertail coverts and comparison with museum study skins because the specimen was in poor condition. Identification of age or sex was not possible.

\section{Discussion}

Three of the six burdock-killed birds were in fairly good condition. The feathers had been matted by rain that had fallen throughout the previous week and the eyes were sunken. The somewhat rancid smell of the birds indicated they had begun to decompose. Their condition suggested that they died some time in the late summer or fall of 2000. In comparison, two of the Nashville Warblers, the second and fourth individuals, and the Tennessee Warbler were mostly decomposed; essentially, only bones and feathers were left. These birds probably died during the spring migration of 2000 or possibly the previous year during fall migration.

Additional evidence for the timing of entrapments comes from our observations of these species in King's Park from late July through the fall of 2000. We observed Nashville Warblers between 24 August and 3 October and Tennessee Warblers between 28 August and 23 September. Empidonax flycatchers were uncommon, and a single bird, unidentified as to species, was seen on 28 August. Adult Least Flycatchers migrate through southern Manitoba from mid-July to early August, whereas immature birds, such as the specimen found, migrate from late July throughout August and occasionally individuals are present until late September. ${ }^{8}$

These birds likely were foraging on or around the burdock plants when they became entangled. Strong winds, which have been suggested as a cause of burdock entrapment, ${ }^{4}$ could have been 
the sole cause or could have contributed to their entanglement. Least Flycatchers forage from the top of the shrub layer up into the canopy (1 to 20 $\mathrm{m}$ off the ground) by hawking aerial insects or gleaning insects from vegetation. ${ }^{2}$ In King's Park, we observed Hermit Thrushes, Tennessee Warblers, Nashville Warblers, Palm Warblers, and Song Sparrows perching in burdock. A Tennessee Warbler perched in and foraged throughout the burdock patch where the third Nashville Warbler specimen was discovered. In addition, several other bird species were observed foraging on the ground below burdock plants or perched on other plants and shrubs among burdock plants. These birds included Common Yellowthroat, Fox Sparrow, Lincoln's Sparrow, White-throated Sparrow, and Indigo Bunting. Larger birds, such as Hermit Thrushes, Fox Sparrows, and White-throated Sparrows probably can free themselves if they become stuck on burs. However, warblers and other small birds encounter a significant risk while foraging or moving about in a patch of burdock.

There was a mixture of ages in the birds we found. The Least Flycather was an immature, whereas there were three adult and one immature Nashville Warbler. These observations suggest that there is no age bias with regards to susceptibility to burdock entanglement, although the sample was small. Sex was identified only for two of the six birds, both female Nashville Warblers, precluding any conclusions on a gender bias to burdock entanglement.

We spent only a few hours searching in this small city park. We were surprised to find so many burdock-killed birds. Our observations suggest that burdock is the cause of many unnoticed songbird deaths each year.

\section{Acknowledgments}

We thank Spencer Sealy for reviewing the manuscript and for assistance with bird species identification, Heidi den Haan for assistance with bird age/sex identification, and Norm Kenkel for assistance with burdock species identification.

1. Atkinson, I. 1989. Introduced animals and extinctions. In: Western, D. and M. C. Pearl (eds.). Conservation for the Twenty-first Century. Oxford University Press, Oxford. p. 54-75.

2. Briskie, J. V. 1984. Least Flycatcher (Empidonax minimus). In: Poole, A. and F. Gill (eds.). The Birds of North America, No. 99. The Academy of Natural Sciences, Philadelphia, and The American Ornitholgists' Union, Washington, D.C.

3. Gross, R. S., P. A. Werner and W. R. Hawthorn. 1980. The biology of Canadian weeds. 38. Arctium minus (Hill) Bernh. and A. lappa L. Canadian Journal of Plant Science 60:621-634.

4. McNicholl, M. K. 1988. Bats and birds stuck in burdock. Prairie Naturalist 20:157-160.

5. McNicholl, M. K. 1994. Additional records of birds caught on burdock. Ontario Birds 12:117-119.

6. Parker, I. M. and S. H. Reichard. 1998. Critical issues in invasion biology for conservation science. In: Fiedler, P. L. and P. M. Kareiva (eds.). Conservation Biology, second edition. Chapman \& Hall, New York. p. 283-305.

7. Pyle, P. 1997. Identification Guide to North American Birds. Part I. Slate Creek Press, Bolinas, CA.

8. Sealy, S. G. and G. C. Biermann. 1983. Timing of breeding and migrations 
in a population of Least Flycatchers in Manitoba. Journal of Field Ornithology 54:113-122.

9. Wilkinson, T. 1999. Songbird deathtraps. Audubon 101(5):23.

10. Williams, J. M. 1996. Nashville Warbler (Vermivora ruficapilla). In:
Poole, A. and F. Gill (eds.). The Birds of North America, No. 205. The Academy of Natural Sciences, Philadelphia, and The American Ornitholgists' Union, Washington, D.C.

11. Zimmer, S. J. and H. A. Kantrud. 1987. Burdock traps kinglet. Prairie Naturalist 19:259-260.

\section{A call for burdock (Arctium spp.) and bird information.}

We are preparing an updated review of records of burdock-entangled birds. Except for records reported in this issue of the Blue Jay and unpublished records from Manitoba (Sealy unpublished data), we are not aware of any records of burdock-entangled birds from the prairie provinces. We encourage individuals to report any unpublished records of birds caught in burdock or observations of birds interacting with burdock. Please contact one of us at the addresses listed below. Any information provided will be acknowledged and greatly appreciated.

Todd J. Underwood, Heather L. Hinam, and Spencer G. Sealy, Department of Zoology, University of Manitoba, Winnipeg, MB R3T 2N2. Email: umunderw@cc.umanitoba.ca, umhinamh@cc.umanitoba.ca, sgsealy@cc.umanitoba.ca

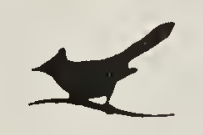

\section{DRAKE CINNAMON TEAL APPARENTLY INCUBATING A CLUTCH OF EGGS AT WHITEWATER LAKE, MB}

CAROLYN CURTIS, 699 Brock Street, Winnipeg, MB R3N $0 Z 3$

A western species, Cinnamon Teal are considered occasional visitants to Manitoba, with roughly 45 records of single males or males accompanied by unidentified females. ${ }^{8}$ They have been recorded almost annually in Manitoba since 1974 in prairie sloughs and sewage lagoons. During the spring and summer of 2000 , four drake Cinnamon Teal were reported from different locations in southwestern Manitoba. To date there have been no nesting records for Manitoba; however, there is one confirmed breeding record for Ontario in $1983 .^{3}$ 